\title{
Fuel properties and rheological behavior of biodiesel from egusi (Colocynthis citrullus L.) seed kernel oil
}

\begin{abstract}
In this study, egusi (Colocynthis citrullus L.) seed kernel oil has been evaluated as a feedstock for biodiesel production. The transesterification of the crude egusi seed kernel oil (CESKO) via methanol in the presence of sodium methoxide was performed and the resulting egusi oil methyl ester (EOME) was tested for its fatty ester composition, fuel properties and rheological behavior (at $25{ }^{\circ} \mathrm{C}, 40{ }^{\circ} \mathrm{C}$ and $55^{\circ} \mathrm{C}$ ). The fuel properties of EOME measured met both the ASTM D6751 and EN 14214 biodiesel standards, with the exception of lower oxidative stability. The fatty ester composition and fuel properties of EOME were found comparable to those of conventional biodiesels from soybean, sunflower and safflower oils. The viscosity behavior of EOME and its blends with diesel fuel (at $25{ }^{\circ} \mathrm{C}, 40{ }^{\circ} \mathrm{C}$ and $55^{\circ} \mathrm{C}$ ) was found to be pseudoplastic and Newtonian in nature and this agrees with those of other biodiesels reported in literature. From this study, the kinematic viscosity of EOME (3.91 $\mathrm{mm} 2 / \mathrm{s})$ was found to be slightly lower than that of most biodiesels $(\geq 4.0 \mathrm{~mm} 2 / \mathrm{s})$ reported in literature.
\end{abstract}

Keyword: Biodiesel; Fuel properties; Egusi kernel oil; Transesterification; Rheology 